\title{
AGRARISM IN BULGARIA AND CZECHOSLOVAKIA IN THE FIRST THIRD OF THE 20TH CENTURY: GENESIS, FEATURES OF DEVELOPMENT, INTELLECTUAL HERITAGE
}

\section{Kompaniiets O. V.}

\section{INTRODUCTION}

In the first third of the 20th century the ideology of agrarianism reached the peak of its popularity in the countries of Central, Eastern and SouthEastern Europe, which was marked by the genesis of its numerous national variants: Bulgarian, Czechoslovakian, Polish, Yugoslavian, Romanian, Ukrainian, Hungarian, German and Baltic.

The historical preconditions and circumstances for the spread of agrarian ideas in this region were defined by K. Galushko: "The ground for its [agrarianism] reception was created by the cheap American grain, that was imported to Europe at the turn of the XIX-XX centuries. Thus, it led to falling of prices for agricultural products and the impoverishment of a large number of peasants in Eastern Europe. In this agrarian region, the slogans of agrarianism were filled with new social and political content and became the doctrine of mass peasant parties, which were unknown in Western Europe"1.

The experience of agrarianism in Bulgaria and Czechoslovakia seems especially interesting and valuable. Developing in different political and socio-economic conditions, in many cases these regional options were at the forefront of the theory and practice of the agrarianism during the "golden age of the European peasantry" - the period between the world wars, when, according A. Toshkov, the peasantry became a political entity, understood its destiny, realized its purpose and self-organized to defend the "third way", alternative to communism and capitalism ${ }^{2}$. At the same time, the historian J. Eellend defined the Bulgarian version as a negative, and the Czechoslovak as a constructive experience of agrarianism ${ }^{3}$.

${ }^{1}$ Галушко К. Гетьманська ідеологія В. Липинського 1920-1929 рр. : проблеми інтерпретації. Студї з архівної справи та документознавства. 1999. Т. 5. С. 67.

${ }^{2}$ Toshkov A. Agrarianism as Modernity in 20th-Century Europe: The Golden Age of the Peasantry. Bloomsbury Academic, 2019. P. 168.

${ }^{3}$ Eellend J. Agrarianism and Modernization in Inter-War Eastern Europe. Societal change and ideological formation among the rural population of the Baltic area 1880-1939/ ed. by P. Wawrzeniuk. Huddinge, 2008. P. 40. 
Historiography of the issue can be systematized into three problemthematic areas. The first includes publications in which the phenomenon of agrarianism in Central and South-Eastern Europe is analyzed in general and the features of its national variants were identified. To the second and third - studies, which focuses on Czechoslovak and Bulgarian agrarianism and agrarian movements of the first third of the 20th century.

Recognized experts in the field of Central and South-Eastern European agrarianism are R. Holec ${ }^{4}$, J. Eellend ${ }^{5}$, Z. Hemmerling ${ }^{6}$, E. Kubů, T. Lorenz, U. Müller ${ }^{7}$, A. Lech ${ }^{8}$, J. Rychlik, L. Holeček, M. Pehr ${ }^{9}$, H. Schultz, A. Harre ${ }^{10}$, A. Toshkov ${ }^{11}$, B. Trencsenyi ${ }^{12}$, J. Wojnicki ${ }^{13}$, A special place belongs to the Soviet historiography of agrarianism and the closely related "Green International", which is represented by the works of M. Goranovich ${ }^{14}$ and A. Noskova ${ }^{15}$. Modern Ukrainian historians-

${ }^{4}$ Holec R. Ideove zdroje medzinarodneho agrarizmu a jeho narodnych špecifik. Agrarni strana a jeji zajmove, družstevni a peněžni organizace. Uherske Hradiště, 2010. Vol. 15. S. 51-72.

${ }^{5}$ Eellend J. (2008). Agrarianism and Modernization in Inter-War Eastern Europe. Societal change and ideological formation among the rural population of the Baltic area 1880-1939. Huddinge, Pp. 35-56.

${ }^{6}$ Hemmerling Z. Ruch ludowy w Polsce Bułgarii i Czechosłowacji, 1893-1930. Warszawa : Ludowa Społdzielnia Wydawnicza, 1987. 456 p.

${ }^{7}$ Kubů E., Lorenz T., Müller U. Agrarismus und Agrareliten in Ostmitteleuropa. Berlin : Berliner Wissenschafts-Verlag, 2013. 686 p.

${ }^{8}$ Lech A. Agraryzm w ruchu ludowym państw słowiańskich (1918-1939). Dzieje partii $i$ stronnictw chłopskich $w$ Europie. Narodziny $i$ rozwoj. Pułtusk-Warszawa, 2007. T. 1. S. 33-42.

${ }^{9}$ Rychlik J., Holeček L., Pehr M. Agrarismus ve středni a vychodní Evropě 19. a 20. stoleti. Praha : CEVRO Institut, 2015. $355 \mathrm{~s}$.

${ }^{10}$ Schultz H., Harre A. Bauerngesellschaften auf dem Wegin die Moderne Agrarismus in Ostmitteleuropa 1880 bis 1960. Wiesbaden : Harrassowitz Verlag, 2010. 296 s.

${ }^{11}$ Toshkov A. Agrarianism as Modernity in 20th-Century Europe: The Golden Age of the Peasantry. Bloomsbury Academic, 2019. 240 p.

${ }^{12}$ Trencsenyi B. Transcending Modernity: Agrarian Populist Visions of Collective Regeneration in Interwar East Central Europe. Regimes of Historicity in Southeastern and Northern Europe, 1890-1945. London, 2014. P. 119-145.

${ }^{13}$ Wojnicki J. Restytucja i przekształcenia ugrupowań agrarnych w państwach Europy Środkowej i Wschodniej. Wschód Europy Studia humanistyczno-społeczne. T. 6(1). 2020. p. 31-52.

${ }^{14}$ Горанович М. Аграрный кризис и распад аграрного блока стран Восточной и Юго-Восточной Европы, 1930-1933. Москва : Наука, 1971. 221 с.; Горанович М. Крах Зеленого Интернационала (1921-1938). Москва : Наука, 1967. 284 с.

15 Носкова А.Ф. К вопросу об аграризме и крестьянском движении в странах Центральной и Юго-Восточной Европы в межвоенный период. Советское славяноведение. 1981. № 2. С. 40-57. 
researchers of the phenomenon of agrarianism are S. Kornovenko ${ }^{16}$, K. Galushko ${ }^{17}$, T. Pikovska ${ }^{18}$, O. Sukhushina ${ }^{19}$. They managed not only to "inscribe" Ukrainian agrarianism in the context of Central and South-Eastern Europe, but also to investigate the cooperation of the emigrant Ukrainian Agrarian Society in Podebrady with representatives of agrarian thought in Czechoslovakia. An article by M. Tomek is devoted to a similar issue ${ }^{20}$,

Well-known experts on Czechoslovak agrarianism are J. Cesar, B. Cerny ${ }^{21}$, J. Harna, V. Lacina ${ }^{22}$, M. Peknik ${ }^{23}$, O. Stepankova ${ }^{24}$, G. Matveev ${ }^{25}$.

Historiography of the Bulgarian variant of agrarianism is represented by works J. Bell ${ }^{26}$, N. Dimov ${ }^{27}$, N. Oren ${ }^{28}$, J. Rubaha ${ }^{29}$, A. Krapivin ${ }^{30}$.

${ }^{16}$ Kornovenko S. The ideology of Eastern European agrarianism in the programmatic provisions of Czechoslovak and Ukrainian political parties (in the face of social and political turmoil of the early 20th century). Acta historica Neosoliensia Vedecký časopis pre historické vedy. 2019. Vol. 22, Issue 2. P. 4-23; Kornovenko S., Pasichna Y. Eastern european agrarianism. Ukrainian intellectual space in the late 19th and early 20th centuries. Украӥнський селянин. 2019. Вип. 22. С. 24-30; Kornovenko S., Zemzulina N. Ukrainian agrarianism as an option of eastern european agrarism in political programs of the ukrainian national parties of the period of the Ukrainian revolution. Український селянин. 2019. Вип. 21. С. 14-20.

${ }^{17}$ Галушко К. Гетьманська ідеологія В. Липинського 1920 - 1929 рр.: проблеми інтерпретації. Студї з архівної справи та документознавства. 1999. Т. 5. С. 64-70; Галушко К. «Хліборобська ідеологія» В. Липинського у системі східноєвропейського аграризму. Украӥнський історичний збірник. 2000. Вип. 2. С. 164-200.

18 Піковська Т.В. Національні програми Чехословацької Республіканської (аграрної) партії (1899-1922 рр.). Гілея: науковий вісник. 2016. Вип. 115. С. 455-458.

${ }^{19}$ Сухушина О.В. Аграрні рухи в слов'янських країнах Центральної і ПівденноСхідної Європи та створення зеленого інтернаціоналу (1921-1924рр.). Украӥнський селянин: 3б. наук. пр. Черкаси, 2008. Вип. 11. С. 337-341.

${ }^{20}$ Tomek M. Ukrajinska monarchisticka emigrace v ČSR a organizace agrarni strany. Regionalni zvlaštnosti politiky agrarni strany v obdobi prvni Československe republiky. Studie Slovackeho Muzea / ed. by J. Harna, B. Rašticova. 2012. Vol. 17. P. 183-192.

21 Cesar J., Cerny B. O ideologii ceskoslovenskeho agrarizmu. Ceskoslovensky casopis historicky. 1959. No. 2. P. 263-285.

${ }^{22}$ Harna J., Lacina V. Politicke programy českeho a slovenskeho agrarniho hnuti, 1899-1938. Praha : Historicky ustav, 2007. 274 p.

${ }^{23}$ Peknik M. Milan Hodža a agrarne hnutie. Bratislava : Ustav politickych vied SAV, 2008. 192 p.

${ }^{24}$ Stepankova O. O ideologii agrarismu. Sbornik praci Filozoficke fakulty brněnske univerzity. 1961. Vol. 10, Iss. G 5. S. 60-69.

${ }^{25}$ Матвеев Г.Ф. «Третий путь?»: Идеология аграризма в Чехословакии и Польше в межвоенный период. Москва: Издательство МГУ, 1992. 239 с.; Матвеев Г. Формирование идеологии чешских аграриев в конце XIX - 1914 г. Вестник Московского университета. Серия 8. «История». 1989. № 5. С. 42-55. 
The popularity of agrarianism in Bulgaria and Czechoslovakia was due to similar reasons: 1) a series of agrarian crises of the late 19th - early 20th century; 2) agrarian overpopulation; 3 ) the threat of unemployment for agricultural workers, given the mechanization of the agricultural sector; 4) significant lag of agriculture in the region compared to Western Europe; 5) the spread in the countries of Central and Eastern and South-Eastern Europe of universal suffrage after the First World War, which allowed the peasants to more significantly influence the political life of their countries. In addition, according to A. Toshkov, the Bulgarian, Czech and Slovak agrarian parties, which before the First World War were on the margins of political life, after 1918 found themselves in a radically transformed sociopolitical landscape in which pre-war political forces and institutions have been discredited, severely weakened, or even expelled from the country. In his view, the autonomous peasant movements that emerged from the ashes of the First World War were represented by three alternatives that were articulated during the "golden age of the European peasantry": agrarian radicalism in Bulgaria; the concept of the peasant nation in Yugoslavia (particularly in Croatia and Serbia) and centrist agrarianism as a guarantor of parliamentary stability in Czechoslovakia ${ }^{31}$. Such a socio-political atmosphere naturally created favorable conditions for the development of agrarianistic ideas.

In addition, we should note several important circumstances that, in our opinion, have influenced the national characteristics of agrarian movements. Thus, at the end of the First World War, the degree of resolution of the agrarian question in different countries was different: in Bulgaria it was extremely acute, in Czechoslovakia - partially resolved, and in Estonia and Latvia agrarian reform was implemented. Also, we can not underestimate the influence of religion on the mentality, worldview and economic ethics of the

${ }^{26}$ Bell J. Peasants in Power: Alexander Stamboliski and the Bulgarian Agrarian National Union, 1899-1923. Princeton University Press, 1977. 273 p.

27 Димов Н. Ал. Стамболийски, аграрните движения в Европа и международната дейност на БЗНС. Александър Стамболийски: живот, дело, завети. София, 1980. C. $363-381$.

28 Oren N. Revolution Administered: Agrarianism and Communism in Bulgaria, Baltimore : Johns Hopkins UP, 1973. 224 p.

${ }^{29}$ Rubacha J. Ruch ludowy w Bułgarii w latach 1914-1944. Studia z Dziejów Rosji i Europy Srodkowo-Wschodniej. 2011. Vol. 46. Р. 63-84.

${ }^{30}$ Крапивин А., Бычихин Ю. Аграризм Димитра Драгиева - вождя болгарских крестьян. Вісник Донецького університету. Серія Б: Гуманітарні науки. 1998. Вип. 2. С. 69-72.

${ }^{31}$ Toshkov A. Agrarianism as Modernity in 20th-Century Europe: The Golden Age of the Peasantry. Bloomsbury Academic, 2019. P. 169. 
predominantly Orthodox peasants of Bulgaria, mostly the Catholic peasants of Czechoslovakia and, for example, the Protestant peasants of Estonia and Latvia.

Let us dwell in more detail on the ideologues and the content of the ideology of agrarianism in Bulgaria and Czechoslovakia.

\section{Agrarianism in Bulgaria}

According to J. Ellend, the most influential agrarian party in Central and Eastern Europe was the Bulgarian Agrarian National Union (BANU) ${ }^{32}$ a party formed in 1899 on the basis of the peasant cooperative movement. A strong foundation of Bulgarian agrarianism in general and the ideology of BANU in particular were laid in the works of Alexander Stamboliyski "Farmer by profession and farmer by conviction" (in Bulg. «Земеделец по занятие и земеделец по убеждение», 1908), "Power, powerlessness and democracy" (in Bulg. «Власт. Безвластие. Народовластие», 1919), "Why farmers unite" (in Bulg. «Защо се сдружават земеделците», 1919), "The Agricultural Union and its enemies" (in Bulg. «Земеделският съюз и неговите врагове», 1919), "The principles of BANU" (in Bulg. «Принципите на БЗНС», 1919), "The difference between the Agrarian Union and the parties" (in Bulg. «Различието между Земеделския съюз и партиите», 1919) and of Dimitar Dragiev "Where is the salvation of Bulgarian farmers?" (in Bulg. «Где е спасението на българските земеделци?», 1908), “Association in the agricultural union" (in Bulg. «Объединението в Земеделския съюз», 1927).

The source of agrarian ideology in Bulgaria were the works of German agrarianists Albert Schaeffle and Gustav Ruhland, that were actively translated during the First World War. Another source were the works of Russian esers (members of the Socialist Revolutionary Party), popular for their large translations and close Bulgarian-Russian cultural and political ties. R. Holec claims that the obtained theoretical product acquired a peculiar and unique Bulgarian form, in which there were more one-sidedness, eclecticism, radical rhetoric, emotional rather than rational arguments. This is one of the reasons why the religious aspect in the Bulgarian version of agrarianism was especially relevant. Bulgarian agrariansists' views on industrialization and urbanization were based not on a scientific analysis of socio-economic development trends, but on an unfounded belief that the

${ }^{32}$ Eellend J. Agrarianism and Modernization in Inter-War Eastern Europe. Societal change and ideological formation among the rural population of the Baltic area 1880-1939 / ed. by P. Wawrzeniuk. Huddinge, 2008. P. 36. 
"industrial epidemic" would disappear and the world would return to a rural way of life ${ }^{33}$.

Leaders of Bulgarian agrarians and, in particular, BANU, in the first quarter of the 20th century were Alexander Stamboliyski and Rayko Daskalov. In September-October 1918, the BANU distinguished itself by participating in the failed anti-government Vladai uprising. In August 1919, in the regular parliamentary elections, the Bulgarian Agrarian National Union received the largest number of votes $-28 \%$, thar brought for the party 85 out of 236 seats $^{34}$. Without a decisive majority in parliament, BANU formed a coalition with populist forces and progressive liberals. Instead, members of the Agrarian Union immediately held key positions in the government and got 7 of the 10 ministerial portfolios in September 1919, including the post of prime minister, which became Alexander Stamboliyski (1919-1923). On May 20, 1920, a new Council of Ministers was formed, and all ten ministerial posts were won by representatives of the agrarian forces. Thus, in addition to the post of Prime Minister, Alexander Stamboliyski headed the Ministries of Foreign Affairs and Military Affairs; Alexander Dimitrov became Minister of Internal Affairs; Tsanko Cherkovsky - Minister of Public Affairs; Marko Turlakov - Minister of Finance; Rayko Daskalov - Minister of Trade; Alexander Radolov Minister of Justice; Stoyan Omarchevsky - Minister of Education; Alexander Obbov - Minister of Agriculture; Nedyalko Atanasov - Minister of Transport, Posts and Telegraph ${ }^{35}$. Thus, Bulgarian Agrarian National Union went down in history as the only agrarian party in Europe that ever came to power with a majority government, not just as part of a coalition.

In his works, Alexander Stamboliyski revealed the image of Bulgaria, which it should become in 20 years of the BANU's rule in Bulgaria. In the future, it was seen by Bulgarian farmers as an "exemplary agricultural state" that would be "free of urban dirt", provided with healthy drinking water, numerous parks, telegraph, telephone and electricity. Alexander Stamboliyski predicted the existence of highly organized cooperatives in the country, an extensive railway network, the existence of storage facilities for grain and tobacco at each station. A House of Agrarian Democracy should be organized in each village, where professional and public discussions,

${ }^{33}$ Holec R. Ideove zdroje medzinarodneho agrarizmu a jeho narodnych špecifik. Agrarni strana a jeji zajmove, družstevni a peněžni organizace. Uherske Hradiště, 2010. Vol. 15. P. 53.

${ }^{34}$ Bell J. Peasants in Power: Alexander Stamboliski and the Bulgarian Agrarian National Union, 1899-1923. Princeton University Press, 1977. P. 143.

${ }^{35}$ Rubacha J. Ruch ludowy w Bułgarii w latach 1914-1944. Studia z Dziejów Rosji i Europy Srodkowo-Wschodniej. 2011. Vol. 46. P. 70-72 
lectures, art games and films would be shown, and farmers would be able to hear "the best speeches of the best speakers". The old parties in Bulgaria were to leave the political arena and be replaced by a coalition formed by the BANU, which would represent the interests of all cooperatives and farmers in the country. Women were to be given the right to vote and play an appropriate role in political life $\mathrm{f}^{36}$.

In practice, however, the primary task facing the new Bulgarian government was to stabilize the postwar situation in the country. All members of the Council of Ministers of the First World War period were arrested, as well as some deputies and journalists who in 1918 advocated the continuation of Bulgaria's participation in the war. Among the economic and social reforms carried out during 1919-1923, the method of solving the agrarian question by Bulgarian agrarians attracts our attention the most. Agrarian reform was carried out in two stages. The first step was the creation of a state land fund through the parcelling of latifundias and large farms, the area of which exceeded 30 hectares for arable land, 20 hectares for forests and pastures, 50 hectares in mountainous areas ${ }^{37}$. The next step was the transfer of land to landless and landless peasants. The components of the agrarian policy of the BANU were the provision of agriculture with cheap loans, as well as the expansion of the network of primary schools.

According to J. Rubacha, the agrarian reform of the BANU was a serious step towards the democratization of land relations, but did not fulfill the expectations placed on it. On the one hand, Bulgaria did not have a large number of plots of land that could be parceled out (so the amount of land accumulated in the fund was relatively small), and on the other hand, its distribution was very slow. As of 1923, the authorities had managed to satisfy only a quarter of the applicants' appeals ${ }^{38}$.

Thanks to its strong positions in parliament and government, the Bulgarian Agrarian National Union began to pursue an almost dictatorial rule, a harsh anti-city and anti-Semitic policy, until its leader, Alexander Stamboliyski, was assassinated in 1923 and power passed to the right. After the coup of 1923, the ideas of agrarianism developed mainly among the Bulgarian emigration. According to R. Holec, they acquired pronounced theoretical (if not utopian) forms: the cooperative line became the core; after 1923 coup d'état, Bulgarian agrarians began to speak more and more actively about the "liquidation of capitalist exploitation" and to justify

\footnotetext{
${ }^{36}$ Стамболийски Ал. Власт. Безвластие. Народовластие. София, 1919. С. 12-18; Стамболийски Ал. Защо се сдружават земеделците? София, 1919. С. 20-31.

${ }^{37}$ Rubacha J. Ruch ludowy w Bułgarii w latach 1914-1944. Studia z Dziejów Rosji i Europy Srodkowo-Wschodniej. 2011. Vol. 46. S. 72.

${ }^{38}$ Ibid. S. 73.
} 
cooperativeism as the basis of social order ${ }^{39}$, At the same time, the idea of a "cooperative society" or even a "cooperative state" as a new socio-economic system, a "third way", an alternative to capitalism and socialism, was further developed among Bulgarian emigrants.

\section{Agrarianism in Czechoslovakia}

In Czechoslovakia, agrarianism was the core ideology of the political program of the Republican Party of Farmers and Peasants, which, according to O. Stepankova, was the most powerful party in Czechoslovakia in the Interwar period ${ }^{40}$. In contrast to the Bulgarian, Czechoslovak ideologues in their theoretical constructions relied on the work of French agrarianists, in particular Jules Melin. The political conditions in which Czechoslovak agrarianism existed in the interwar period can be considered unique to Central, Eastern and South-Eastern Europe, because, in the words of contemporaries, Czechoslovakia was "an island of democracy in a sea of dictatorships" $"$. Czechoslovak agrarian parties maintained strong positions in parliament and government during the 1920's and 1930's, establishing themselves as reliable coalition partners.

The most influential representatives of Czechoslovak agrarianism were Antonin Švehla and Milan Hodža. A. Švehla headed the Republican Party of Farmers and Peasants from 1909 to 1933, and from 1922 to 1929 he was the Prime Minister of Czechoslovakia. In 1925 he published a theoretical pamphlet "Three Reflections on Agrarianism" 42 . M. Hodža, who belonged to the same party as Švehla, held the post of Minister of Agriculture from 1922 to 1926 and 1932 to 1935, and Prime Minister of Czechoslovakia from 1935 to 1938. In 1930 he published a pamphlet "Agrarianism: a series of lectures "on the ideology of Czechoslovak political parties" $\gg$ ", and a year later - organized a collection of articles, speeches and research "Ways of Central European Agrarian Democracy"44. M. Hodža's views were once popular not only in Czechoslovakia, but also, for example, in Slovenia.

${ }^{39}$ Holec R. Ideove zdroje medzinarodneho agrarizmu a jeho narodnych špecifik. Agrarni strana a jeji zajmove, družstevni a peněžni organizace. Uherske Hradiště, 2010. Vol. 15. P. 54.

${ }^{40}$ Stepankova O. O ideologii agrarismu. Sbornik praci Filozoficke fakulty brněnske univerzity. 1961. Vol. 10, Iss. G 5. S. 60.

${ }^{41}$ for more see: Miller D. Forging Political Compromise: Antonín Svehla and the Czechoslovak Republican Party, 1918-1933. University of Pittsburgh Press, 1999. 344 p.

42 Švehla A. Tři uvahy o agrarismu. Praha : MAB, 1925. $19 \mathrm{~s}$.

${ }^{43}$ Hodža M. Agrarism: Cyklus přednašek "o ideologii českoslov. politickych stran". Praha : ÚSČS, 1930. $16 \mathrm{~s}$.

44 Hodža M. Članky, reči, študie. Sväzok IV, Cesty stredoevropskej agrarnej demokracie 1921-1931. Praha : Novina, 1931. 560 p. 
In September 1924, he took part in the First All-Slavic Congress of Peasant Youth, held in Ljubljana, where he delivered a report "Agrarianism in Slovenia" ${ }^{45}$, that same year was published as a separate brochure.

In 1923, the Czech historian Otakar Frankenberger published "Agrarianism: The National Economy from the Perspective of the Rural Population" 46 , in which he recorded the attitude of the rural population to economic issues and proved the importance of strong and self-sufficient agriculture, which, according to the author, should be the basis of the state. In addition, the publication raised issues of production, distribution of pensions, insurance, implementation of agrarian reform, organizing of agricultural taxation and more. One of the chapters of the book was devoted to a review of the agrarian history of Europe. In 1931, under the influence of the World economic crisis of 1929, another book by O. Frankenberger, imbued with the ideas of agrarianism, was published - "Agrarian crisis and means of its solving" 47 . As a strategy for Czechoslovakia's exit from the economic crisis, O. Frankenberger proposed the idea of solidarity, as well as cooperation - the consolidation of agricultural enterprises for efficient mechanization without alienating small and medium-sized owners from land. Proponents of agrarianism tended to expand the functions of the state in the field of social and economic relations, including agriculture.

Also in 1931, another source for the history and philosophy of agrarianism was published in Prague - the work of Josef Kettner "Liberalism, Socialism and Agrarianism"48. According to the author, agrarianism during the 19th century developed along with socialism as opposed to liberalism. However, agrarianism wanted to avoid the mistakes of two competing ideological currents. First, unlike socialism, it does not set unattainable goals and is based on real life. Second, agrarianism has an ideal model: agrarian democracy, which, unlike socialism, is achieved through evolution and reform, not through revolutionary struggle. The meaning of agrarianism, according to $\mathrm{J}$. Kettner, is social justice, ie equality of rights and responsibilities ${ }^{49}$.

${ }^{45}$ Hodža M. Agrarizem in Slovanstvo. Ljubljana : Kmetijska tiskovna zadruga, 1924. $16 \mathrm{~s}$.

${ }^{46}$ Frankenberger O. Agrarismus : Narodní hospodařstvi se stanoviska venkovskeho lidu. Praha : A. Neubert, 1923. 416 p.

${ }^{47}$ Frankenberger O. Zemědělska krise a prostředky k jejimu řešení. Praha : Nákladem České národohospodářské společnosti, 1931. P. 37.

${ }^{48}$ Ibid. P. 60.

${ }^{49}$ Kettner J. Liberalismus, socialismus a agrarismus. Praha : Svobodné učení selské, 1931. P. 18. 
Compared to other national variants of agrarianism, Czechoslovakia had the most extensive network of periodicals. The daily newspapers "The Village" ("Venkov"), "The Evening" ("Večer"), "The People's Diary" ("Lidovy Denik"), "The Freedom" ("Svoboda"), "The Slovak Diary" ("Slovensky Denik") and "The Slovak Politics" ("Slovenska Politika") were agrarianistic in content and spirit. In addition to daily newspapers, the "Republican Party of Farmers and Peasants" published 9 weeklies, 3 monthly magazines, and 24 regional periodicals.

The generalization of the theoretical foundations of Czechoslovak agrarianism was undoubtedly a series of M. Hodža's public lectures "Agrarianism", with which he delivered in 1930, and later published ${ }^{50}$. In his works and speeches, M. Hodža argued that the peasantry and agriculture play a leading role in the society of Czechoslovakia. At the same time, he acknowledged that the main factor in the last quarter of the 19th century was the labor movement. The First World War, however, caused such changes that the most influential social factors, according to M. Hodža, became the agrarian aristocracy and agrarian democracy. These changes took place mainly in the countries of Central Europe, where M. Hodža discovered "a bloodless, quiet, but the deepest social revolution in world history". According to M. Hodža, this revolution took place in Czechoslovakia, Poland, Romania, Yugoslavia, Bulgaria, Greece, the Baltic States and Finland. Therefore, these countries, in the socio-economic life of which farming played a significant role, according to M. Hodža, "were the most progressive factor against the weary civilization of the West, where factories and machines that mechanized people predominated, and against Russia, where the communist regime existed only through the killing of people" ${ }^{, 52}$. Finally, M. Hodža emphasized in every way that the energy of the labor force and the environment create in the farmer such characteristics that allow him to act as a "savior of society". It is interesting that this thesis of the ideologue of Czechoslovak agrarianism is in many aspects consonant with the ideas of the Ukrainian economist, physician and philosopher S. Podolynsky ("Human Labor and the Unity of Physical Forces", 1880).

Czechoslovak agrarians unanimously condemned large-scale feudal land tenure, considering it not only an anachronism but also a morally unjust phenomenon. Unlike Bulgarian agrarians, the idea of allotting land to the

${ }^{50}$ Hodža M. Agrarism: Cyklus přednašek «o ideologii českoslov. politickych stran». Praha: ÚSČS, 1930. 16 P.; Hodža M. Članky, reči, študie. Sväzok IV, Cesty stredoevropskej agrarnej demokracie 1921-1931. Praha : Novina, 1931. 560 P.

${ }^{51}$ Hodža M. Agrarism: Cyklus přednašek «o ideologii českoslov. politickych stran». Praha : ÚSČS, 1930. P. 4-5.

52 Ibid. P. 9. 
entire agricultural population has not become widespread in Czechoslovakia. Czechoslovak agrarianism was generally negative about the large industrial bourgeoisie. Private property was defined as a guarantee of economic, social and moral stability of society ${ }^{53}$. In the 1920's, the ideology of the "third way" became popular among Czechoslovak agrarians, in particular supporters of M. Hodža, according to which the state had the right to interfere into business activity, as well as to act as a social arbiter.

\section{Bulgarian and Czechoslovak agrarianism in the context of the search for a "third way" in Central and Eastern Europe in the first third of the 20th century}

The fundamental difference between the ideologies of Czechoslovak and Bulgarian agrarianism lies in the moderate nature of the first and the radicalism of the second. Thus, Czechoslovak theorists of agrarianism were against any kind of dictatorship that was considered to degrade the social order and human dignity and contradict the democratic nature of the peasant. Because dictatorship is inextricably linked to the concentration of power, it makes it impossible to achieve social stability, which is one of the main tasks of agrarianism. Consequently, the dictatorship could not provide a representation of peasant interests and morals.

Agrarianism in Central and Eastern and South-Eastern Europe was a transnational phenomenon characterized by the relocation of centers, the intensive transfer of ideas that went beyond the region, and supranational institution building. The linguistic closeness of the Slavic nations facilitated the exchange of theoretical approaches between the representatives of agrarian thought in the region. Another aspect of intensive international relations among agrarianists were personal contacts. Examples of this are the visits of the leaders of the agrarian parties of neighboring countries to Bulgaria during 1919-1923, as well as the visit of A. Stamboliyski to Czechoslovakia.

The International Agrarian Bureau (the so-called Green International), established in 1921 in Prague, represented the ideas of agrarianism in the international arena. Its founders were agrarian parties from Bulgaria, Czechoslovakia, Croatia and Poland. According to A. Toshkov, the Bureau was a counterweight to the International Peasants' Council, better known as the Peasant International ("Krestintern"), which emerged in Moscow in $1923^{54}$.

53 Матвеев Г. Ф. «Третий путь?»: Идеология аграризма в Чехословакии и Польше в межвоенный период. Москва : Издательство МГУ, 1992. С. 18-20.

${ }^{54}$ Toshkov A. Agrarianism as Modernity in 20th-Century Europe: The Golden Age of the Peasantry. Bloomsbury Academic, 2019. P. 170. 
The paradox of the Bulgarian version of agrarianism is that the Bulgarian Agrarian National Union, which was the most influential among the national parties of agrarian orientation, was the first in Central and Eastern and South-Eastern Europe that lost power, paving the way for the authoritarian regime (1923). After Bulgaria, agrarian forces suffered political defeat in Poland (1926), Yugoslavia (1929), Romania (1931), Estonia, and Latvia (1934). In Czechoslovakia, on the other hand, the Republican Party of Farmers and Peasants maintained its popularity and political weight until 1938 and its representation in government through various coalitions.

In the Interwar period, agrarianism acquired the most radical features (not by accident) in Bulgaria and Croatia, two agrarian countries of Southeastern Europe at the time. On the contrary, parliamentary-oriented and moderate agrarian movements emerged in countries with relatively developed industries, such as Czechoslovakia.

In the Central and Eastern European agrarianism, J. Eellend distinguishes two main types: progressive agrarianism, focused on farmers (Czechoslovakia) and traditionalist agrarianism, focused on small and medium-scale peasants (Bulgaria) ${ }^{55}$. In Soviet historiography, there was an opinion that the Bulgarian Agrarian National Union was the only party of the Green International that did not deny capitalism ${ }^{56}$. On the other hand, the further agrarianism expand the Eastern or Southeastern Europe, the more its ideology acquired anti-capitalist, patriarchal features, turning into a utopia. One of the brightest representatives of this variant of agrarianism, scientists consider the dictatorship of A. Stamboliyski in Bulgaria.

From the point of view of theoretical principles and political practice, the closest to the Czechoslovak variant of agrarianism were Latvian and Estonian. Instead, Bulgarian agrarianism seems to be the closest to the Croatian version.

\section{CONCLUSIONS}

The uniqueness of the Bulgarian and Czechoslovak variants of agrarianism of the first third of the 20th century was due to a number of circumstances and facts.

Features of Bulgarian agrarianism: 1) the development of agrarian thought in Bulgaria was significantly influenced by German and Russian agrarianism; 2) Bulgarian Agrarian National Union - it is one of the oldest

${ }^{55}$ Eellend J. Agrarianism and Modernization in Inter-War Eastern Europe. Societal change and ideological formation among the rural population of the Baltic area 1880-1939 / ed. by P. Wawrzeniuk. Huddinge, 2008. P. 37.

${ }^{56}$ Горанович М. Крах Зеленого Интернационала (1921-1938). Москва : Наука, 1967. C. 7. 
and most influential political parties of agrarian orientation in Central and Eastern and South-Eastern Europe; 3) the Bulgarian version is a striking example of the traditional version of agrarianism, focused on small and medium-scale peasants; 4) Bulgarian agrarianism was the most radical variant of the ideology of European agrarianism, which, in contrast to the democratic tactics, defended the idea of establishing a dictatorship; 5) the ideology of Bulgarian agrarianism in 1910's - 1920's had anti-urban, anti-Semitic and religious aspects; 6) Bulgarian agrarians were the first among the agrarian parties of Central and South-Eastern Europe that came to power (1919), but also lost it first (1923); 7) The Bulgarian Agrarian National Union became the only agrarian party in Interwar Europe that ever come to power with a majority government, not just as part of a coalition.

Features of Czechoslovak agrarianism: 1) it's genesis and development in Czechoslovakia was significantly influenced by French agrarianism; 2) Czechoslovakia had the most developed industry (after Germany) in Central and Eastern Europe, and relatively democratic political system, which created specific conditions for the development of agrarianism in the interwar period; 3) the agrarian parties of Czechoslovakia during the Interwar period maintained strong positions in parliament and government; 4) the popularity of agrarianism in Czechoslovakia persisted until the end of the 1930's, when in other countries of Central and Eastern and SouthEastern Europe it declined or disappeared at all; 5) Czechoslovak agrarianism of the Interwar period was represented by the widest network of periodicals in Europe; 6) the Czechoslovak organization was the most powerful in the International Agrarian Bureau; 7) focused on farming, the Czechoslovak variant was one of the most moderate and most progressive version of agrarianism; 8) at the turn of the 1920's and 1930's, active cooperation between Czechoslovak and Ukrainian agrarists occured, the most notable center of which was the Ukrainian Agrarian Society in Podebrady.

Despite a number of differences and peculiarities of the program principles of the Bulgarian Agrarian National Union and the Republican Party of Farmers and Peasants (Czechoslovakia), their ideology was equally based on peasant centrism, as evidenced by the link between the political and socio-economic future of Bulgaria and Czechoslovakia and the peasantry. 


\section{REFERENCES}

1. Галушко К. Гетьманська ідеологія В. Липинського 1920-1929 рр.: проблеми інтерпретації. Студї з архівної справи та документознавства. 1999. Т. 5. С. 64-70.

2. Галушко К. «Хліборобська ідеологія» В. Липинського у системі східноєвропейського аграризму. Украӥнський історичний збірник. 2000. Вип. 2. С. 164-200.

3. Горанович М. Аграрный кризис и распад аграрного блока стран Восточной и Юго-Восточной Европы, 1930-1933. Москва : Наука, 1971. $221 \mathrm{c}$.

4. Горанович М. Крах Зеленого Интернационала (1921-1938). Москва : Наука, 1967. 284 с.

5. Димов Н. Ал. Стамболийски, аграрните движения в Европа и международната дейност на БЗНС. Александър Стамболийски: живот, дело, завети. София, 1980. С. 363-381.

6. Крапивин А., Бычихин Ю. Аграризм Димитра Драгиева - вождя болгарских крестьян. Вісник Донещького університету. Серія Б: Гуманітарні науки. 1998. Вип. 2. С. 69-72.

7. Матвеев Г.Ф. «Третий путь?»: Идеология аграризма в Чехословакии и Польше в межвоенный период. Москва : Издательство МГУ, 1992. $239 \mathrm{c.}$

8. Матвеев Г. Формирование идеологии чешских аграриев в конце XIX - 1914 г. Вестник Московского университета. Серия 8. «История». 1989. № 5. С. 42-55.

9. Носкова А.Ф. К вопросу об аграризме и крестьянском движении в странах Центральной и Юго-Восточной Европы в межвоенный период. Советское славяноведение. 1981. № 2. С. 40-57.

10. Піковська Т.В. Національні програми Чехословацької Республіканської (аграрної) партії (1899-1922рр.). Гілея: науковий вісник. 2016. Вип. 115. С. 455-458.

11. Стамболийски Ал. Власт. Безвластие. Народовластие. София, 1919. С. $12-18$.

12. Стамболийски Ал. Защо се сдружават земеделците? София, 1919. C. $20-31$.

13. Сухушина О.В. Аграрні рухи в слов'янських країнах Центральної i Південно-Східної Європи та створення зеленого інтернаціоналу (1921-1924рр.). Украӥнський селянин : зб. наук. пр. Черкаси, 2008. Вип. 11. С. 337-341.

14. Bell J. Peasants in Power: Alexander Stamboliski and the Bulgarian Agrarian National Union, 1899-1923. Princeton University Press, 1977. 273 p. 
15. Cesar J., Cerny B. O ideologii ceskoslovenskeho agrarizmu. Ceskoslovensky casopis historicky. 1959. No. 2. P. 263-285.

16. Eellend J. Agrarianism and Modernization in Inter-War Eastern Europe. Societal change and ideological formation among the rural population of the Baltic area 1880-1939 / ed. by P. Wawrzeniuk. Huddinge, 2008. P. 35-56.

17. Frankenberger O. Agrarismus : Narodní hospodařstvi se stanoviska venkovskeho lidu. Praha : A. Neubert, 1923. $416 \mathrm{~s}$.

18. Frankenberger $\mathrm{O}$. Zemědělska krise a prostředky $\mathrm{k}$ jejimu řešení. Praha : Nákladem České národohospodářské společnosti, 1931. 37 s.

19. Harna J., Lacina V. Politicke programy českeho a slovenskeho agrarniho hnuti, 1899-1938. Praha : Historicky ustav, 2007. 274 p.

20. Hemmerling Z. Ruch ludowy w Polsce Bułgarii i Czechosłowacji, 1893-1930. Warszawa : Ludowa Społdzielnia Wydawnicza, 1987. $456 \mathrm{~s}$.

21. Hodža M. Agrarism: Cyklus přednašek "o ideologii českoslov. politickych stran”. Praha : ÚSČS, 1930. 16 p.

22. Hodža M. Agrarizem in Slovanstvo. Ljubljana : Kmetijska tiskovna zadruga, 1924. $16 \mathrm{p}$.

23. Hodža M. Članky, reči, študie. Sväzok IV, Cesty stredoevropskej agrarnej demokracie 1921-1931. Praha : Novina, 1931. 560 p.

24. Holec R. Ideove zdroje medzinarodneho agrarizmu a jeho narodnych špecifik. Agrarni strana a jeji zajmove, družstevni a peněžni organizace. Uherske Hradiště, 2010. Vol. 15. P. 51-72.

25. Kettner J. Liberalismus, socialismus a agrarismus. Praha : Svobodné učení selské, $1931.60 \mathrm{p}$.

26. Kornovenko S. The ideology of Eastern European agrarianism in the programmatic provisions of Czechoslovak and Ukrainian political parties (in the face of social and political turmoil of the early 20th century). Acta historica Neosoliensia Vedecký časopis pre historické vedy. 2019. Vol. 22, Issue 2. P. 4-23.

27. Kornovenko S., Pasichna Y. Eastern european agrarianism. Ukrainian intellectual space in the late 19th and early 20th centuries. Український селянин. 2019. Вип. 22. С. 24-30.

28. Kornovenko S., Zemzulina N. Ukrainian agrarianism as an option of eastern european agrarism in political programs of the ukrainian national parties of the period of the Ukrainian revolution. Український селянин. 2019. Вип. 21. С. 14-20.

29. Kubů E., Lorenz T., Müller U. Agrarismus und Agrareliten in Ostmitteleuropa. Berlin : Berliner Wissenschafts-Verlag, 2013. 686 p.

30. Lech A. Agraryzm w ruchu ludowym państw słowiańskich (1918-1939). Dzieje partii i stronnictw chłopskich w Europie. Narodziny i rozwoj. Pultusk-Warszawa, 2007. T. 1. S. 33-42. 
31. Miller D. Forging Political Compromise: Antonín Svehla and the Czechoslovak Republican Party, 1918-1933. University of Pittsburgh Press, 1999. $344 \mathrm{p}$.

32. Oren N. Revolution Administered: Agrarianism and Communism in Bulgaria, Baltimore : Johns Hopkins UP, 1973. 224 p.

33. Peknik M. Milan Hodža a agrarne hnutie. Bratislava : Ustav politickych vied SAV, 2008. $192 \mathrm{p}$.

34. Rubacha J. Ruch ludowy w Bułgarii w latach 1914-1944. Studia z Dziejów Rosji i Europy Srodkowo-Wschodniej. 2011. Vol. 46. P. 63-84.

35. Rychlik J., Holeček L., Pehr M. Agrarismus ve středni a vychodní Evropě 19. a 20. stoleti. Praha: CEVRO Institut, 2015. 355 p.

36. Schultz H., Harre A. Bauerngesellschaften auf dem Wegin die Moderne Agrarismus in Ostmitteleuropa 1880 bis 1960. Wiesbaden : Harrassowitz Verlag, 2010. 296 p.

37. Stepankova O. O ideologii agrarismu. Sbornik praci Filozoficke fakulty brněnske univerzity. 1961. Vol. 10, Iss. G 5. P. 60-69.

38. Švehla A. Tři uvahy o agrarismu. Praha : MAB, 1925. $19 \mathrm{~s}$.

39. Tomek M. Ukrajinska monarchisticka emigrace v ČSR a organizace agrarni strany. Regionalni zvlaštnosti politiky agrarni strany v obdobi prvni Československe republiky. Studie Slovackeho Muzea / ed. by J. Harna, B. Rašticova. 2012. Vol. 17. P. 183-192.

40. Toshkov A. Agrarianism as Modernity in 20th-Century Europe: The Golden Age of the Peasantry. Bloomsbury Academic, 2019. 240 p.

41. Trencsenyi B. Transcending Modernity: Agrarian Populist Visions of Collective Regeneration in Interwar East Central Europe. Regimes of Historicity in Southeastern and Northern Europe, 1890-1945. London, 2014. P. 119-145.

42. Wojnicki J. Restytucja i przekształcenia ugrupowań agrarnych w państwach Europy Środkowej i Wschodniej. Wschód Europy Studia humanistyczno-spoteczne. T. 6(1). 2020. P. 31-52. 